\title{
Transforming Growth Factor- $\alpha$ Gene Expression in Late-Gestation Fetal Rat Lung
}

\author{
JOSEPH KUBIAK, MONALISA M. MITRA, A. REGINA STEVE, JAY D. HUNT, PAUL DAVIES, \\ AND BRUCE, R. PITT \\ Department of Pharmacology, University of Pittsburgh School of Medicine, Pittsburgh, Pennsylvania 15261
}

\begin{abstract}
Transforming growth factor- $\alpha$ (TGF- $\alpha$ ) is a structural homologue of epidermal growth factor and competes for binding on a common transmembrane protein receptor/kinase. Although TGF- $\alpha$ appears to be more important than epidermal growth factor in embryogenesis and mammalian organogenesis, there is little information regarding its expression in developing lung. Accordingly, we measured levels of immunoreactive TGF- $\alpha$ and its gene expression in late-term fetal rat lung during the transition from the canalicular (19-20 d) to the saccular (21 d) stage. We report that at 19 d gestation intrapulmonary levels of TGF- $\alpha$ were $1.4 \pm 0.3 \mathrm{pmol} / \mathrm{mg}$ protein as determined by RIA, but had decreased by $50 \%$ at $21 \mathrm{~d}$. To determine if the TGF- $\alpha$ gene is expressed in lung, RNA isolated from fetal rat lung was reverse transcribed, and a 302-bp fragment corresponding to a portion of the TGF- $\alpha$ gene was amplified by polymerase chain reaction. Southern blot hybridization with a ${ }^{32} \mathrm{P}$-labeled 2.3-kb EcoRI fragment of rat TGF- $\alpha$ cDNA clone showed a pattern of declining expression during late gestation. Therefore, fetal rat lung expresses TGF- $\alpha$, as is evidenced by the synthesis of both the message and the protein. Because levels of protein were highest in the period of canalicular lung development when the respiratory acinus is formed and vascularized, a potential role for this intrapulmonary growth factor in pulmonary remodeling is suggested. (Pediatr Res 31: 286-290, 1992)
\end{abstract}

\section{Abbreviations}

TGF- $\alpha$, transforming growth factor- $\alpha$

EGF, epidermal growth factor

EGF-R, epidermal growth factor receptor

IR-TGF- $\alpha$, immuno reactive TGF- $\alpha$

$\mathrm{PCR}$, polymerase chain reaction

SSC, sodium chloride, sodium citrate

TGF- $\alpha$ is a structural homologue of EGF. The mitogenic and nonproliferative effects of $\mathrm{TGF}-\alpha$ and $\mathrm{EGF}$ are initiated by binding of either ligand to a common transmembrane protein receptor, EGF-R. An important role for these polypeptide regulatory factors in development has been suggested by the characterization of high-affinity EGF-R on murine embryonic (1) and fetal rodent (2) tissue as well as human placenta (3). With immunologic and molecular analytical methodology, the consen-

Received April 11, 1991 ; accepted November 1, 1991.

Correspondence and reprint requests: Dr. Bruce R. Pitt, Department of Pharmacology, University of Pittsburgh School of Medicine, Pittsburgh, PA 15261.

Supported in part by an American Lung Association Fellowship (J.S.K.) and by National Heart, Lung, and Blood Institute Grants HL-32154 and HL-41811. The work was performed during the tenure of B.R.P. as an Established Investigator of the American Heart Association. sus has grown that TGF- $\alpha$, and not EGF, is the more abundant, and perhaps critical, fetal growth factor of the two (4-7).

It seems likely that the above growth factors play an important role in fetal lung development as well. EGF receptors are abundant in fetal lung tissue (8-10), and exogenous EGF can 1) stimulate proliferation of epithelial cells in conducting airways of fetal lambs in vivo (11) and fetal human epithelial type II cells in vitro (12),2) accelerate lung maturation of fetal rabbits in vivo (8) and rat alveolar epithelial cells in vitro $(13,14)$, and 3 ) accelerate differentiation of tracheal mucous secretory cells in fetal rhesus monkey in utero (15). Despite the widespread distribution of EGF-R in the fetal lung and the effectiveness of exogenous EGF, relatively little is known about endogenous ligands for the EGF-R. EGF precursor mRNA and epitopes common to this precursor have been localized to the developing mouse lung by using in situ hybridization and immunodetection techniques, respectively, and confirmed with PCR detection of fetal mouse lung EGF precursor RNA (37). In late gestational human lung, immunoreactive EGF is limited to nonmucous cells of the submucosal glands of the upper airways (16). In fetal sheep, a novel alternative EGF-R ligand, lipocortin-1, has been immunolocalized in airway epithelium (10).

We were interested in identifying TGF- $\alpha$ in fetal lung during the transition from canalicular to saccular stages. This abrupt transition is characterized by significant vascularization and remodeling of peripheral lung. TGF- $\alpha$ may be particularly relevant because it is more potent than EGF in promoting angiogenesis (17) and affecting other aspects of remodeling $(18,19)$. We selected the rat because the transition from canalicular to saccular stages is condensed into a $3-d$ preterm period, d 19 to 21 of gestation. In the current report, we show for the first time that immunoreactive TGF- $\alpha$ is present in fetal rat lung during this period. Its local synthesis is suggested by the fact that TGF- $\alpha$ specific DNA fragments, amplified by PCR of reverse transcribed fetal rat lung RNA, were clearly identified.

\section{MATERIALS AND METHODS}

Animals. Pregnant female Sprague-Dawley rats (Charles River Laboratories, Inc., Wilmington, MA) were killed with an overdose of sodium pentobarbital on d 19-21 of gestation. Gestational age was determined by appearance of vaginal plug and later confirmed by histologic examination of lung structure. After opening the abdominal cavity and exteriorizing the uterine horns, individual amniotic sacs were rapidly isolated. Amniotic fluid was aspirated from the anterior region of each sac, pooled, clarified by centrifugation at $4^{\circ} \mathrm{C}$, and frozen at $-70^{\circ} \mathrm{C}$ until needed for the determination of TGF- $\alpha$ protein levels. Fetal lungs and placentae were then obtained by sterile dissection from five litters each at 19,20, and $21 \mathrm{~d}$ gestation. The lungs from six or seven fetuses were pooled on ice and stored at $-70^{\circ} \mathrm{C}$ until needed for determination of TGF- $\alpha$ protein levels. Three placentae were pooled for the same purpose. The lungs from remaining fetuses were used immediately for RNA isolation. Lungs of two 
mature male rats were also processed to compare expression of TGF- $\alpha$ mRNA in the adult.

Morphology. Lungs from fetuses not used for protein or mRNA determinations were immersion-fixed in $2 \%$ glutaraldehyde, $1 \%$ paraformaldehyde in $100 \mathrm{mM}$ sodium cacodylate, $\mathrm{pH}$ 7.4. They were dehydrated in graded ethanol solutions and embedded in methacrylate. Sections $1-2 \mu \mathrm{m}$ thick were cut, stained in $1 \%$ methylene blue, and examined on a Nikon Mikrophot (Niles, IL) photomicroscope.

Quantification of $T G F-\alpha$ by RIA. TGF- $\alpha$ was extracted from the fetal lungs and placentae using a modification of the acidethanol method described by Roberts et al. (20). Frozen lungs and placentae were thawed at $4^{\circ} \mathrm{C}$ in a solution consisting of phenylmethylsulfonyl fluoride and pepstatin in ethanol and $\mathrm{HCl}$ : Tissue was homogenized with a glass plunger and allowed to stand overnight at $4^{\circ} \mathrm{C}$. The mixture was centrifuged, and the pellet was reextracted in a solution of ethanol, water, and $\mathrm{HCl}$ (77:22:1). The combined supernatants from both extractions were adjusted to $\mathrm{pH} 5.2$ with ammonium hydroxide and then diluted in ammonium acetate buffer, $\mathrm{pH}$ 5.3. This mixture was precipitated in anhydrous ethanol and ether $(1: 2)$ and allowed to stand at $-20^{\circ} \mathrm{C}$ for $36-48 \mathrm{~h}$. The precipitate was dissolved in 1 $\mathrm{M}$ acetic acid and the soluble extract was dialyzed (Spectrapor tubing MWCO 3500 ) against $0.17 \mathrm{M}$ acetic acid at $4^{\circ} \mathrm{C}$ and lyophilized. Lyophilized acid-ethanol extract from fetal lungs (and placenta) was dissolved in PBS at $4^{\circ} \mathrm{C}$ and centrifuged at $13000 \times g$, and soluble extracts were used for protein determination using the method of Lowry et al. (21). Aliquots of amniotic fluid were similarly assayed for protein. Lung and placental extract (and amniotic fluid) were adjusted to a final protein concentration of $0.5 \mathrm{mg} / \mathrm{mL}$ in PBS, $\mathrm{pH} 7.4$. All samples (and standards) were pretreated with an alkaline buffered detergent solution provided by the manufacturer (Biotope Inc., Seattle, WA) to adjust to $\mathrm{pH}>7.4$. Aliquots of TGF- $\alpha$ standards and samples were assayed in duplicate. Nonspecifically bound tracer was determined using normal rabbit IgG. Incubation of specific rabbit anti-rat TGF- $\alpha,{ }^{125} \mathrm{I}$-TGF- $\alpha$, and the sample (or standard) proceeded for $16 \mathrm{~h}$ at $4^{\circ} \mathrm{C}$. There is no cross-reactivity with EGF even with a large excess (Biotope Inc.).

Isolation of total RNA. Total cellular RNA was isolated from fresh lung and placental samples using the single step method of Chomczynski and Sacchi (22). Briefly, lungs and placentae were homogenized at room temperature in a denaturing solution containing $4 \mathrm{M}$ guanidinium isothiocyanate, and RNA was isolated by extraction with a phenol/chloroform mixture. After precipitation of RNA with isopropanol, the pellet was washed with $75 \%$ ethanol and solubilized in $0.5 \%$ SDS. RNA concentrations were determined by spectrophotometry at $260 \mathrm{~nm}$. An aliquot of total RNA was applied to an oligodeoxythymidine cellulose chromatographic column from which the polyadenylated [poly $\left(\mathrm{A}^{+}\right)$] fraction was isolated.

Northern blot analysis of $R N A$. Total $(10 \mu \mathrm{g})$ and poly $(\mathrm{A})^{+}$ $(0.2 \mu \mathrm{g})$ RNA were electrophoresed in $1 \%$ agarose-formaldehyde gels, blotted onto Genescreen (New England Nuclear, Boston, MA), and hybridized with a 2.3-kb EcoRI fragment of TGF- $\alpha$ cDNA clone. Hybridization conditions were based on those described by Church and Gilbert (23) with modifications by Amasino (24). Both prehybridization and hybridization buffers contained $50 \%$ deionized formamide, $0.25 \mathrm{M} \mathrm{NaHPO}_{4}$ (pH 7.2), $0.25 \mathrm{M} \mathrm{NaCl}, 1 \mathrm{mM}$ EDTA, $7 \% \mathrm{SDS}$, and $100 \mu \mathrm{g} / \mathrm{mL}$ denatured salmon sperm DNA. Probes were labeled with ${ }^{32} \mathrm{P}$-deoxycytidine triphosphate using the random primer DNA labeling method of Feinberg and Vogelstein (25). Approximately $1 \times 10^{7} \mathrm{cpm}$ per filter were used in the hybridization solution. Filters were first briefly rinsed with $2 \times \mathrm{SSC}(0.1 \%$ SDS followed by two washes each for $15 \mathrm{~min}$ with $2 \times \mathrm{SSC}) 0.1 \% \mathrm{SDS}, 25 \mathrm{mM} \mathrm{NaHPO}_{4}(\mathrm{pH}$ 7.2)-1 mM EDTA-0.1\% SDS, and $25 \mathrm{mM} \mathrm{NaHPO}_{4}$ (pH 7.2)-1 $\mathrm{mM}$ EDTA- $1 \%$ SDS. All washes were done at $50^{\circ} \mathrm{C}$. Filters were then exposed to Kodak X-Omat X-ray film for variable periods of time.
An additional aliquot $(2 \mu \mathrm{g})$ of total RNA from lung and placenta was applied (slot-blotted) directly on to Genescreen via vacuum filtration and hybridized with a ${ }^{32} \mathrm{P}$-labeled $\beta$-actin cDNA probe.

$P C R$ amplification of fetal and adult $R N A$. This procedure was carried out in two steps: reverse transcription of total RNA from lungs followed by PCR of the resulting cDNA. Total RNA (5 $\mu \mathrm{g})$ from 19- to 21-d fetal lungs and two male adult lungs was reverse transcribed by using $60 \mathrm{U}$ of avian myeloblastosis virus reverse transcriptase (Boehringer Mannheim Biochemicals) primed with $0.5 \mu \mathrm{g}$ of oligo(dT) (Pharmacia, Inc., Piscataway, $\mathrm{NJ})$ in a $50-\mu \mathrm{L}$ reaction mixture for $1 \mathrm{~h}$ at $37^{\circ} \mathrm{C}(26)$. Twenty percent of the cDNA obtained from the above reaction was subjected to amplification with $0.5 \mathrm{U}$ of Ampli Taq DNA polymerase (Perkin-Elmer Cetus, Norwalk, CT) and $0.2 \mu \mathrm{M}$ of TGF- $\alpha$ specific primers (see below) in a standard $50 \mu \mathrm{L}$ PCR mixture (27) for 30 cycles. All amplification reactions were done in a Thermal Cycler (Perkin-Elmer Cetus). Each cycle consisted of 1 min denaturation at $94^{\circ} \mathrm{C}, 2$ min reannealing at $55^{\circ} \mathrm{C}$, and 1 min primer extension at $72^{\circ} \mathrm{C}$ that was increased by $20 \mathrm{~s}$ in every cycle. The products of the reactions were fractionated in $1.8 \%$ agarose gels in $1 \times$ Tris-borate-EDTA buffer $(\mathrm{pH} 8.3)$ and transferred to GeneScreen Plus (New England Nuclear) for southern blot hybridization (see below). The oligonucleotide primers were designed on the basis of the TGF- $\alpha$ cDNA sequence published by Blasband et al. (28), with the $5^{\prime}$ primer spanning the region between nucleotides 133 and 150 and the $3^{\prime}$ primer lying between nucleotides 418 and 435 . This led to amplification of a $302-b p$ fragment of DNA. In addition, a separate aliquot (20\%) of the above cDNA was subjected to identical amplification protocols except that primers $(0.2 \mu \mathrm{M})$ were specific for human $\beta$-actin. The $5^{\prime}$ primer spanned the region between nucleotides 1344 and 1363 and the $3^{\prime}$ primer lay between nucleotides 1627 and 1651. This led to amplification of a 307-bp fragment of DNA.

Southern blot analysis of amplified DNA. DNA fragments were transferred from agarose gels to GeneScreen Plus overnight in an alkaline solution $(0.4 \mathrm{~N} \mathrm{NaOH} ; 0.6 \mathrm{M} \mathrm{NaCl})$. Filters were then neutralized for $15 \mathrm{~min}$ in $0.5 \mathrm{M}$ Tris, $1 \mathrm{M} \mathrm{NaCl}$, pH 7.5, and dried at room temperature. This was followed by prehybridization at $47^{\circ} \mathrm{C}$ for $4 \mathrm{~h}$ in $1 \mathrm{M} \mathrm{NaCl} ; 50 \mathrm{mM}$ Tris, $\mathrm{pH} 7.5 ; 1 \%$ SDS, $100 \mu \mathrm{g} / \mathrm{mL}$ heat denatured salmon sperm DNA, $1 \times$ Denhardt's solution, $30 \%$ formamide, and $10 \%$ dextran sulfate. Hybridization was carried out in the same buffer with approximately $2-3 \times 10^{6} \mathrm{cpm}$ of probe DNA overnight at $47^{\circ} \mathrm{C}$. For TGF- $\alpha$, the probe used was a 2.3-kb EcoRI fragment of a rat TGF- $\alpha$ cDNA clone kindly provided by Dr. David Lee (University of North Carolina, Chapel Hill, NC). For $\beta$-actin, the probe used was a $1.8-\mathrm{kb}$ BamHI fragment of a human $\beta$-actin cDNA clone. Filters were washed twice with $2 \times$ SSC- $0.1 \%$ SDS for 50 min each at $50^{\circ} \mathrm{C}$. The washed filters were dried briefly and autoradiographed on Kodak X-Omat x-ray film for varying periods of time. Hybridization signal was determined by scanning densitometry (LKB Ultrascan XL; Pharmacia LKB) of autoradiographic exposure. The signal area associated with amplified fragment for TGF- $\alpha$ or $\beta$-actin was determined by integration with LKB 2400 GelScan software. The ratio of TGF- $\alpha$ to $\beta$-actin RNA signal was calculated for comparative purposes.

Statistical analysis. TGF- $\alpha$ levels are reported as mean \pm SEM. Comparisons between different gestational ages were made by one-way analysis of variance followed by testing of individual means by Newman-Keuls multiple range test (29). Differences at the $5 \%$ level were considered significant.

\section{RESULTS}

Morphology. At $19 \mathrm{~d}$ gestation, the morphology of the lungs was typical of a late pseudoglandular, early canalicular phase of development. The mesenchymal stroma was extensive, and airways were still tubular with relatively large cuboidal epithelial 
cells; however, vascularization was already apparent (Fig. $1 A$ ). At $20 \mathrm{~d}$, the typically canalicular morphology was present with obvious evidence of airway branching (Fig. $1 B$ ). At $21 \mathrm{~d}$, the formation of the saccules was virtually complete and the lining epithelium was no longer principally cuboidal (Fig. 1C).

Quantification of TGF- $\alpha$ by RIA. Mean levels of IR-TGF- $\alpha$ are shown during late gestation in lung (Fig. 2), placenta (Fig. 3), and amniotic fluid (Fig. 4). At $19 \mathrm{~d}$ gestation, mean intrapulmonary IR-TGF- $\alpha$ was $1.4 \pm 0.3 \mathrm{pmol} / \mathrm{mg}$ protein and decreased to $0.7 \pm 0.1 \mathrm{pmol} / \mathrm{mg}$ protein at $21 \mathrm{~d}(p<0.05)$. Placental IRTGF- $\alpha$ was virtually identical to lung IR-TGF- $\alpha$ with respect to quantity of protein and change during late gestation (Fig. 3). Amniotic IR-TGF- $\alpha$, expressed as pmol/mg protein, was $1.5 \pm$ $0.4,2.0 \pm 0.2$, and $2.5 \pm 0.3$, at 19,20 , and $21 \mathrm{~d}$ gestation,
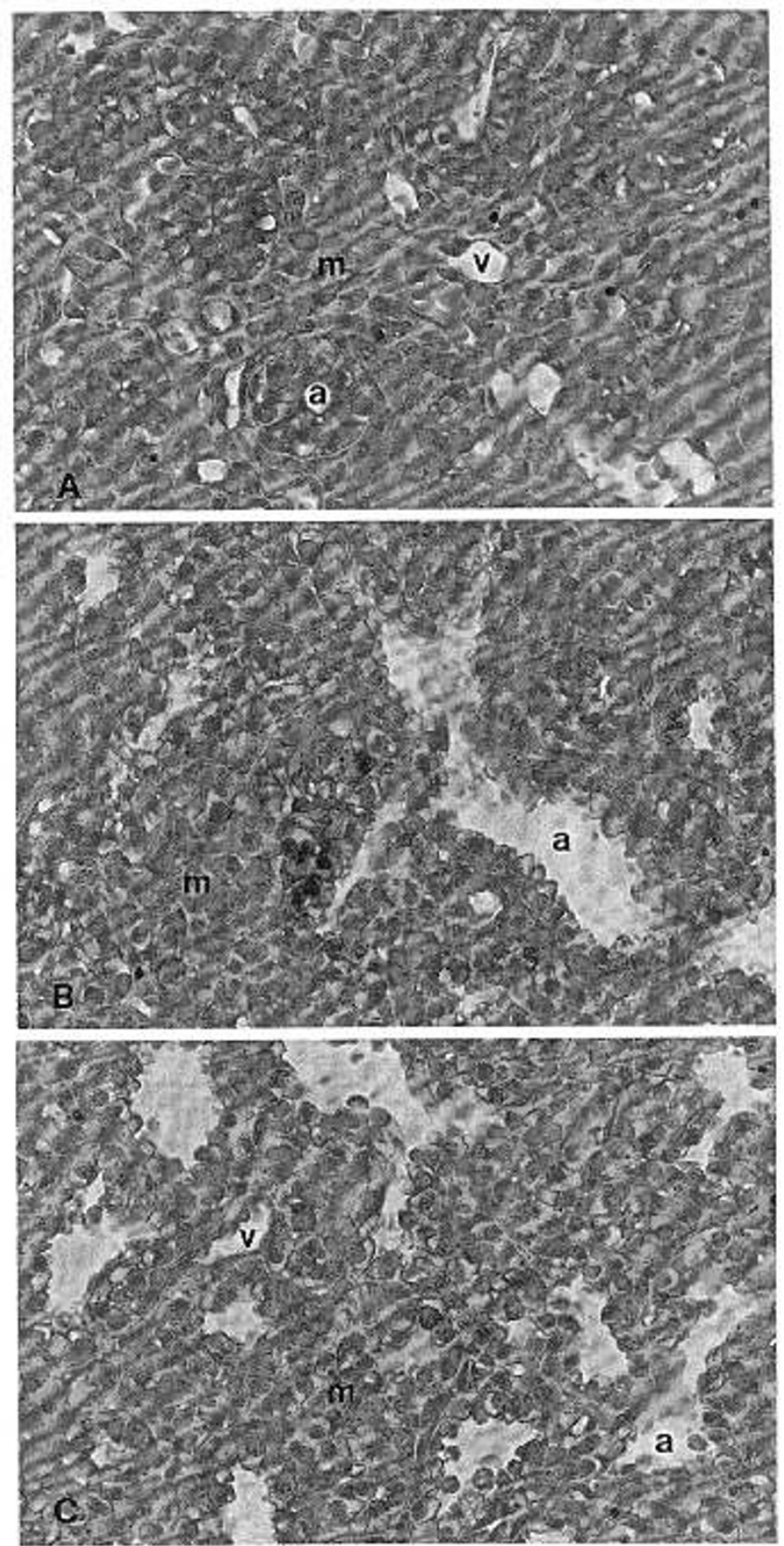

Fig. 1. Photomicrographs of lung tissue from rat fetuses at 19-21 d of gestation. $a$, airways; $m$, mesenchymal stroma; and $v$, vessels. Original magnification $\times 1250$. $A, 19 \mathrm{~d} ; B, 20 \mathrm{~d}$; and $C, 21 \mathrm{~d}$.

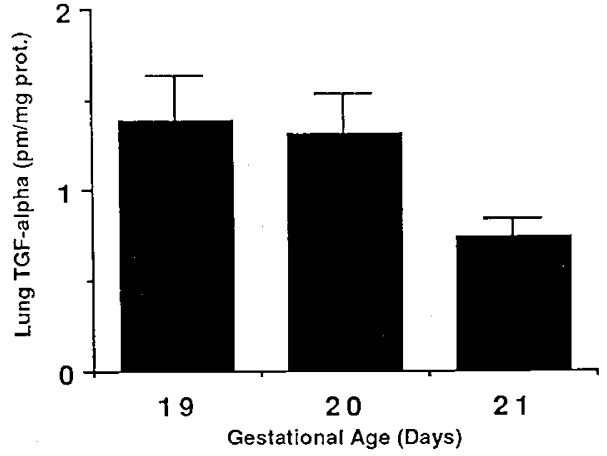

Fig. 2. Levels of TGF- $\alpha$ in fetal lung during late gestation, as determined by RIA. Data are mean \pm SEM of five litters in each respective gestational age group.

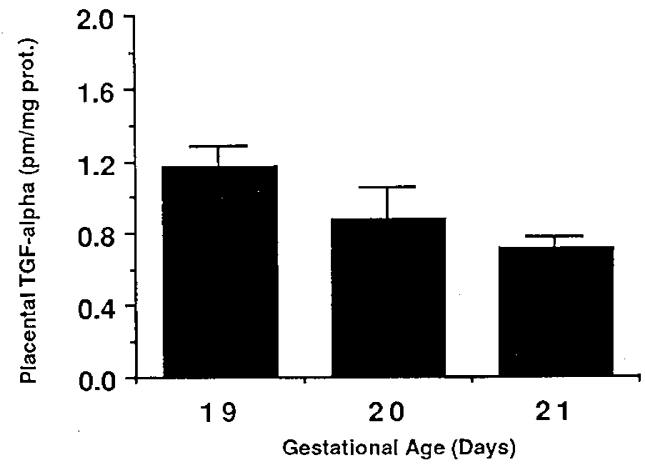

Fig. 3. Levels of TGF- $\alpha$ in placenta during late gestation. Data are mean \pm SEM of five litters in each respective age group.

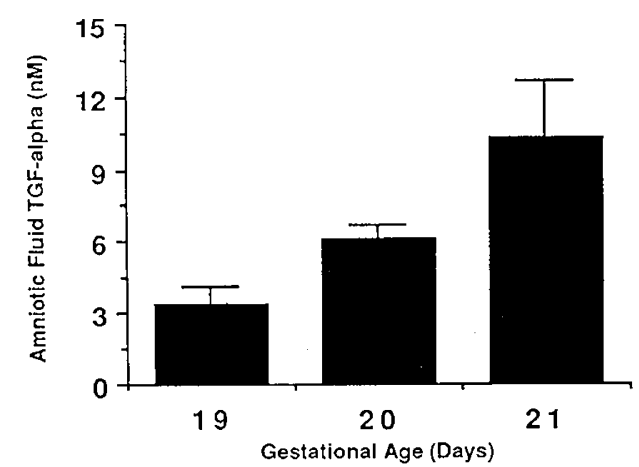

Fig. 4. Levels of TGF- $\alpha$ in amniotic fluid during late gestation. Data are mean \pm SEM of four, five, and three litters in amniotic fluid removed from 19-, 20-, and 21-d gestational animals, respectively.

respectively. Because total protein in amniotic fluid increased near term, amniotic fluid (IR-TGF- $\alpha$, expressed in molar units) increased (Fig. 4; d 21: $p<0.05$ ).

Analysis of $T G F-\alpha m R N A$ expression. Initial attempts to identify TGF- $\alpha$ mRNA in fetal and adult rat lungs by Northern blot hybridization with a cDNA probe did not show any visible signals on autoradiograms (data not shown). This analysis was done using both total and poly $\left(\mathrm{A}^{+}\right)$RNA. Subsequently, total RNA was isolated from fetal lungs and reverse transcribed, and a 302$\mathrm{bp}$ fragment of DNA corresponding to a portion of the TGF- $\alpha$ gene was targeted for amplification. After $30-60$ cycles of PCR, we observed (via ethidium bromide staining of agarose gels) that the amplified DNA was present in variable quantities at different gestational ages. Southern blot hybridization (Fig. 5) showed that the amplified DNA fragment hybridized with the rat TGF- $\alpha$ cDNA probe and that the intensity of the signal was greatest in 19- and 20-d lung and was less in lungs from two 21-d gestation pups. There was a weak, but detectable, signal in one of two 
A

\section{Southern Blots}

$\therefore$ ㅇำ

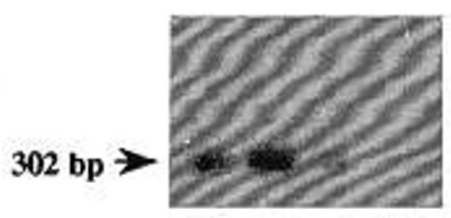

307 bp

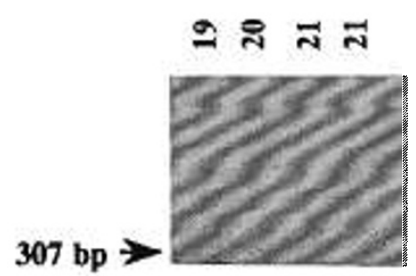

TGF- $\alpha$

B-Actin

B

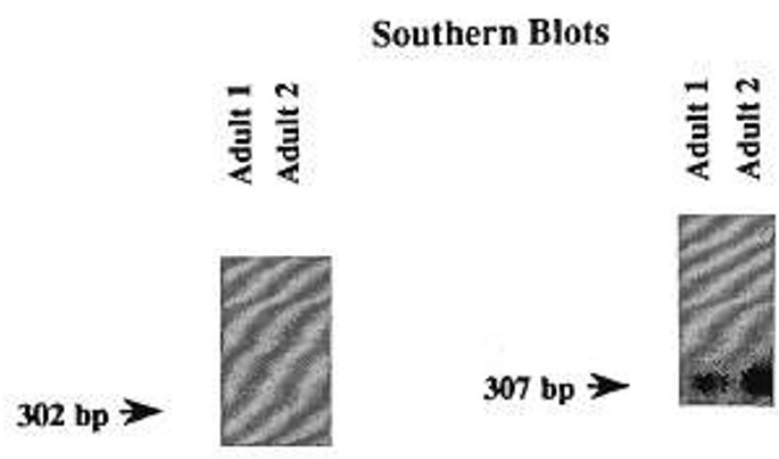

TGF- $\alpha$

\section{B̈-Actin}

Fig. 5. Autoradiogram generated by Southern analysis of DNA amplified by PCR from the CDNA obtained by reverse transcription of RNA extracted from fetal lung of gestational age 19-, 20-, and 21- $(n=$ $2) \mathrm{d}$ rats $(A)$ and two mature male rats $(B)$. Autoradiogram on left-hand side of each panel is after amplification with primers from rat TGF- $\alpha$ gene and autoradiogram on right-hand side is after amplification of an aliquot of above PCR product with primers designed from human $\beta$ actin gene. Results shown are after 30 cycles of amplification. The size of the targeted fragment is indicated with an arrow on the left-hand side of each Southern blot and is based on molecular weight markers.

adult lungs. The pattern of intensity was not likely due to differences in the amount of RNA initially amplified because 1 ) ethidium bromide staining of RNA that was electrophoresed on $1 \%$ agarose formaldehyde gels showed distinct ribosomal bands of the same degree of intensity and 2) RNA $(2 \mu \mathrm{g})$ slot-blotted onto GeneScreen and hybridized with $\beta$-actin revealed similar signals among different age groups (data not shown). Amplification of $\beta$-actin from an aliquot of PCR products (from above) and Southern analysis revealed a similar pattern of intensity among fetal lungs and a three to four times greater intensity in the two mature lungs. Accordingly, normalized hybridization signals for TGF- $\alpha$ were 5.0, 4.4, 2.8, and 1.0 for 19-, 20-, 21-, and 21-d gestational lungs, respectively, and were undetectable and 0.2 in two mature lungs (from Fig. 5).

\section{DISCUSSION}

This is the first complete study that reports significant levels of TGF- $\alpha$ in late gestational rat lung (Fig. 2) and amniotic fluid (Fig. 4). Although the source of TGF- $\alpha$ in lungs is unclear, detection of mRNA in lung (Fig. 5) for this growth factor is consistent with intrapulmonary synthesis. We confirmed by light microscopy (Fig. 1) that an abrupt transition between a canalicular and saccular stage occurs around d 21 of gestation and noted that levels of TGF- $\alpha$ protein (Fig. 2) and mRNA (Fig. 5) were higher in the canalicular than saccular fetal lung. Detection of increasing concentrations of TGF- $\alpha$ in amniotic fluid (Fig. 4) over this period of development suggests that this compartment may be an important medium for the distribution of TGF- $\alpha$.

Morphogenesis of late-gestational rat lung. An important aspect of the current study was to correlate changes in TGF- $\alpha$ levels with structural changes known to occur in the distal portion of the developing lung. In rat, transformation from canalicular to saccular stages occurs within a period of approximately $24 \mathrm{~h}$ and, accordingly, it is critical to document histologically the ultrastructure of the tissue in which TGF- $\alpha$ protein and message is quantified. In Figure 1, we confirm previous studies (30) by showing that the 19- to 20-d fetal rat lung is in a canalicular period and by $\mathrm{d} 21$ it has become saccular in appearance.

$T G F-\alpha$ and lung development. We chose to focus on the expression of TGF- $\alpha$ rather than other endogenous ligands for the EGF-R (including EGF itself) in late-gestational rat lung because previous reports suggest that TGF- $\alpha$ is likely to be the fetal ligand for this receptor (4-7). Although several investigators have concluded that TGF- $\alpha$ (or related proteins) and not EGF may be the more important growth factor of this family in developing ovine kidney (31) and human fetal gut (32), the nature of the endogenous ligands of EGF-R in developing mammals is nonetheless a highly controversial area. A significant amount of this controversy is due to the rareness of respective mRNA transcripts and the potential for significant localization or clustering of its expression (see below). Relatively high levels of TGF- $\alpha$ have been reported in early rat embryos (5), but this result was challenged by Han et al. (33), who suggested that expression of TGF- $\alpha$ mRNA is the result of decidual and not embryonic tissue. Subsequently, Rappolee et al. (26) used PCR techniques to demonstrate expression of TGF- $\alpha$ mRNA in preimplantation embryos, suggesting that the embryo is indeed capable of synthesizing this growth factor. Previously, using standard immunologic and slot-blot hybridization techniques, it was reported that there was no detectable EGF protein (6) or mRNA (34), but there was both detectable protein (6) and message (7) for TGF- $\alpha$. Subsequently, EGF precursor mRNA was detected in clusters of cells of developing mouse teeth and lung, and epitopes common to this EGF precursor were immunolocalized in both epithelial and mesenchymal tissue of mouse lung (35). In human lung, immunoreactive EGF was detected in nonmucous cells of tracheal and bronchial glands, but was absent from the distal budding portion of the developing lung, suggesting a role for growth factors other than EGF in distal remodeling in human lung development (16). In developing sheep, EGF-R have been localized by immunohistochemistry to the upper airways where colocalization of a novel ligand, lipocortin-1, for this receptor has been reported (10).

The current study is the first to quantify TGF- $\alpha$ in the lung during later stages of gestation. The levels measured in lung (Fig. 2) were similar to those simultaneously measured in placenta (Fig. 3), a tissue previously shown to have measurable levels of TGF- $\alpha$ (36). A preliminary report by Brown and Fisher (37) indicating that intrapulmonary TGF- $\alpha$ levels were higher than TGF- $\alpha$ levels in liver, brain, or kidney in late-gestational rat support an organ-specific ontogeny for this growth factor. In addition, we suggest that pulmonary TGF- $\alpha$ is probably synthesized within lung, inasmuch as we detected mRNA for TGF- $\alpha$ in the same tissue (Fig. 5). It is also highly likely that TGF- $\alpha$ 
measured in amniotic fluid (Fig. 4) was derived in part from intrapulmonary sources. Accordingly, fetal lung fluid may serve as a medium for the distribution of TGF- $\alpha$ (and other growth factors). The relatively high levels of message (Fig. 5) noted in the rat lung during the canalicular phase are consistent with a preliminary report in nonhuman primates, which showed that mRNA for TGF- $\alpha$ peaked in this same period of lung development. In human lung development, levels were higher somewhat earlier (38).

Our studies do not allow definitive statements to be drawn regarding precise levels of mRNA for TGF- $\alpha$. Theoretically, a single mRNA for TGF- $\alpha$ passed through 60 cycles of PCR would amplify the message greater than $10^{17}$ times. Our inability to detect any TGF- $\alpha$ mRNA by Northern blot hybridization suggests that the initial amount of TGF- $\alpha$ mRNA in fetal lungs must have been low. Several possibilities may account for the extraordinarily low levels of TGF- $\alpha$ mRNA. First, expression could be vital to the development of a highly localized area of lung such that it makes up only a very small portion of total RNA expressed. Discrete localization of mRNA for TGF- $\alpha$ in mouse fetus has been described to explain previous differences between localization of message to specialized structures of rat fetus (7) and localization to only maternal decidual structures of rat placenta (33). Secondly, mRNA for TGF- $\alpha$ may be highly unstable, thereby accounting for the extended amplification required to detect its presence.

In summary, late-gestational fetal rat lung contains measurable amounts of IR-TGF- $\alpha$. Although the source of TGF- $\alpha$ in lung is unclear, detection of mRNA in lung and TGF- $\alpha$ protein in amniotic fluid are consistent with intrapulmonary synthesis. Peak levels of TGF- $\alpha$ (Fig. 2) and its message (Fig. 5) occurred during a period of considerable remodeling in fetal lung (Fig. 1: canalicular) and abruptly decreased during a more quiescent period (saccular), which is consistent with a potential role for TGF- $\alpha$ in changes known to occur in late-gestational lung.

\section{REFERENCES}

1. Adamson ED, Meek J 1984 The ontogeny of epidermal growth factor receptors during mouse development. Dev Biol 103:62-70

2. Nexo E, Hollenberg MD, Figueroa A, Pratt RM 1980 Detection of epidermal growth factor-urogastrone and its receptor during fetal development. Proc Natl Acad Sci USA 77:2782-2785

3. O'Keefe E, Hollenberg MD, Cuatrecasas P 1974 Epidermal growth factor characteristics of specific binding in membranes from liver, placenta, and other target tissues. Arch Biochem Biophys 164:518-526

4. Matrisian LM, Pathak M, Magun BE 1982 Identification of an epidermal growth factor-related transforming growth factor from rat fetuses. Biochem Biophys Res Commun 107:761-769

5. Lee DC, Rochford R, Todaro GJ, Villareall LP 1985 Developmental expression of rat transforming growth factor-a mRNA. Mol Cell Biol 5:3644-3646

6. Twardzik DR 1985 Differential expression of transforming growth factor- $\alpha$ during prenatal development of the mouse. Cancer Res 45:5413-5416

7. Wilcox JN, Derynck R 1988 Developmental expression of transforming growth factors alpha and beta in mouse fetus. Mol Cell Biol 8:34215-3422

8. Catterton WZ, Escoberdo MB, Sexton WR, Gray ME, Sundell HW, Stahlman MT 1979 Effects of epidermal growth factor on lung maturation in fetal rabbits. Pediatr Res 13:104-108

9. Adamson ED, Deller MJ, Warshaw JB 1981 Functional EGF receptors are present on mouse embryo tissues. Nature 291:656-658

10. Johnson MD, Gray ME, Carpenter G, Pepinsky RB, Sundell H, Stahlman MT 1989 Ontogeny of epidermal growth factor receptor/kinase and of lipocortin1 in the ovine lung. Pediatr Res 25:535-541

11. Sundell HW, Gray ME, Serenius FS, Escobedo MD, Stahlman MT 1980 Effects of epidermal growth factor on lung maturation in fetal lambs. Am J Pathol 100:707-726

12. Messmer TO, Armour R, Holley RW 1982 Factors influencing the growth of alveolar type II epithelial cells isolated from rat lungs. Exp Cell Res 142: $417-426$
13. Gross I, Dynia DW, Rooney SA, Smart DA, Warshaw JB, Sissom JF, Hoath SB 1986 Influence of epidermal growth factor on fetal rat lung development in vitro. Pediatr Res 20:473-477

14. Whitsett JA, Weaver TE, Lieberman MA, Clark JC, Daughtery C 1987 Differential effects of epidermal growth factor and transforming growth factor- $\beta$ on synthesis of $\mathrm{Mr}=35,000$ surfactant associated protein in fetal lung. J Biol Chem 262:7908-7913

15. St George JA, Read LC, Cranz DL, Tarantal AF, George-Nascimento C, Plopper CG 1991 Effect of epidermal growth factor on the fetal development of the tracheobronchial secretory apparatus in rhesus monkey. Am J Respir Cell Mol Biol 4:95-101

16. Stahlman MT, Orth DN, Gray ME 1989 Immunocytochemical localization of epidermal growth factor in the developing human respiratory system and in acute and chronic lung disease in the neonate. Lab Invest 60:539-547

17. Schreiber AB, Winkler ME, Derynck R 1986 Transforming growth factor- $\alpha$ : a more potent angiogenic mediator than epidermal growth factor. Science 232: $1250-1253$

18. Ibbotson KJ, Harrod J, Gowen M, D'Souza S, Smith DD, Winkler ME, Derynck R, Mundy GR 1986 Human recombinant transforming growth factor alpha stimulates bone resorption and inhibits formation in vitro. Proc Natl Acad Sci USA 83:2228-2232

19. Schultz GS, White M, Mitchell R, Brown B, Lynch J, Twardzik DR, Todaro GJ 1987 Epithelial wound healing enhanced by transforming growth factor alpha and a vaccinia growth factor. Science 235:350-352

20. Roberts AB, Lamb LC, Newton DL, Sporn MB, Delarco JE, Todaro GJ 1980 Transforming growth factors: isolation of polypeptide virally and chemically transformed cells by acid/ethanol extraction. Proc Natl Acad Sci USA 77: 3494-3498

21. Lowry OH, Rosebrough NJ, Farr AL, Randall RJ 1951 Protein measurement with the Folin phenol reagent. J Biol Chem 193:265-275

22. Chomczynski $P$, Sacchi N 1987 Single-step method of RNA isolation by guanidium thiocyanate-phenol-chloroform extraction. Anal Biochem 162: 156-159

23. Church GM, Gilbert W 1984 Genomic sequencing. Proc Natl Acad Sci USA 81:1991-1995

24. Amasino RM 1986 Acceleration of nucleic acid hybridization rate by polyethylene glycol. Anal Biochem 152:304-307

25. Feinberg AP, Vogelstein B 1984 Addendum: a technique for radiolabeling DNA restriction endonuclease fragments to high specific activity. Anal Biochem 137:266-267

26. Rappolee DA, Brenner CA, Schultz R, Mark D, Werb Z 1988 Developmental expression of PDGF, TGF- $\alpha$, and TGF- $\beta$ genes in preimplantation mouse embryos. Science 241:1823-1825

27. Saiki RK, Gelfand DH, Stoffel SS, Scharf SJ, Higuchi R, Horn GT, Mullis KB, Erlich HA 1988 Primer-directed enzymatic amplification of DNA with a thermostable DNA polymerase. Science 239:487-491

28. Blasband AJ, Rogers KT, Chen X, Azizkhan AC, Lee DC 1990 Characterization of the rat transforming alpha gene and identification of promoter sequences. Mol Cell Biol 10:2111-2121

29. Zar JH 1984 Biostatistical Analysis, 2nd Ed. Prentice-Hall, Englewood Cliffs, $\mathrm{NJ}$

30. Davies P, de Mello D, Reid LM 1990 Structural methods in the study of development of the lung. In: Gil J (ed) Models of Lung Disease, Microscopy and Structural Methods. Marcel Dekker, New York, pp 409-472

31. Freeman M, Comer M 1988 Epidermal growth factor (EGF)-like transforming growth factor (TGF) activity and EGF receptors in ovine fetal tissues: possible role for TGF in ovine fetal development. Pediatr Res 22:609-615

32. Miettinen PJ, Perheentupa J, Otonkoski T, Lahteenmaki A, Panula P 1989 EGF- and TGF- $\alpha$-like peptides in human fetal gut. Pediatr Res 26:25-30

33. Han VKM, Hunter III ES, Pratt RM, Zemdegio JG, Lee DC 1987 Expression of rat transforming growth factor alpha mRNA during development occurs predominantly in the maternal decidua. Mol Cell Biol 7:2335-2343

34. Popliker M, Shatz A, Avivi A, Ullrich A, Schlessinger J, Webb CG 1987 Onset of endogenous synthesis of epidermal growth factor in neonatal mice. Dev Biol 119:38-44

35. Snead ML, Luo W, Oliver P, Nakamura M, Don-Wheeler G, Bessem C, Bell GI, Rall LB, Slavkin HC 1989 Localization of epidermal growth factor precursor in tooth and lung during embryonic mouse development. Dev Biol 134:420-429

36. Stromberg K, Pigott DA, Ranchalis JE, Twardzik DR 1982 Human term placenta contains transforming growth factors. Biochem Biophys Res Commun 106:354-361

37. Brown PI, Fisher DA 1989 Ontogeny of alpha-transforming growth factor in the rat. Pediatr Res 25:47A(abstr)

38. Strandjord TP, Madtes DK, Hodson WA, Clark JG 1990 Transforming growth factor alpha mRNA expression in developing primate lung. Am Rev Respir Dis 141:A343(abstr) 